Original Contribution

\title{
ANALYSIS OF INCOME DETERMINANTS AMONG RURAL HOUSEHOLDS IN KWARA STATE, NIGERIA
}

\author{
A. E. A. Fadipe, A. H. Adenuga*, A. Lawal \\ Department of Agricultural Economics and Farm Management, University of Ilorin, Ilorin, \\ Nigeria
}

\begin{abstract}
In spite of the various poverty alleviation programmes embarked upon by the Nigerian government to reduce poverty, a large proportion of the populace remain poor. This study was therefore carried out to evaluate the determinants of income among rural households in Kwara State, Nigeria. Data was collected using a well structured questionnaire from 90 randomly selected households. Descriptive statistics and the multiple regression analysis were the major analytical tools employed for the study. The result of the analysis showed that Farm income is the most important source of income for rural households in the study area making up 57.9\% of total household income. Level of education of the household head, farm size and access to electricity and gender of the household head were identified as the major determinant of household income in the study area. The study recommends that these income determinants should be carefully integrated in rural development policies in order to improve the rural household's purchasing power as well as the income distribution in the study area.
\end{abstract}

Key words: Income; Rural households; gender; Farm and Poverty

\section{INTRODUCTION}

More than $70 \%$ of the world's 1.8 billion poor live in rural areas, most of them in developing countries (1). Three out of every four poor people in developing countries live in rural areas (2). On the average, about 80 to 90 percent in Asia and Africa, of all target poverty groups are located in the rural areas (3). Poverty is mainly a rural phenomena but with large regional disparities. Rural poverty is more prevalent, deeper, and more severe than urban poverty (4). Rural poverty is further pronounced in unlimited employed and income generating opportunities due to the absence of commercial and industrial facilities or lack of the necessary resources to establish them. Theoretically, the rural areas of a region or country lie outside the densely-built up environments of towns, cities and sub-urban villages and their inhabitants are engaged primarily in agriculture as well as the most basic of rudimentary form of secondary and tertiary activities (5).

*Correspondence to: Adenuga A. H., Department of Agricultural Economics and Farm Management P.M.B 1515, University of Ilorin, Ilorin, Nigeria, adenugahenry@gmail.com,+2348030404468
Nigeria, though richly endowed, available statistics reveals that the poverty incidence in the country has been on the increase since the 1980s (6). Widening income inequalities and growing poverty in Nigeria are not moving in tandem with the nation's Gross Domestic Product. According to the National Bureau of Statistics (7), 60.9 percent as against 54 percent in 2004, of the Nigerian population or approximately 100 million people live in abject poverty. This class of people lives on less than $\$ 1$ or N160 a day. Income inequality among the populace has also increased by 4.1 percent nationally between 2004 and 2010. It is of knowledge that in spite of the previous efforts of various governments to alleviate poverty in Nigeria and the efforts of the current government to effect same, nothing much had changed in the living conditions and standards of the people especially those in the rural areas. The high level of income poverty in the rural areas predisposes the population to disease, hunger, deprivation, want and premature death.

According to Adebayo (8), the income level of rural communities may be attributed to certain crucial factors, and understanding these factors 
may hold the keys to effective rural development policy formulation. A closer look at the determinants of rural income would provide an in-depth knowledge into the factors that explain low income yield and poverty in rural regions (9). This study therefore provides a very useful insight into the various income generating activities in rural households in Nigeria. Specifically, the study examined the participation rate of the rural households in different income sources and identified the factors influencing income distribution among rural households in the study area.

\section{METHODOLOGY}

\section{Study Area}

The study was conducted in Kwara State, Nigeria. The State is located in the agroecological zone of Nigeria with Ilorin as its capital. The natural vegetation consists broadly of rain forest and wooded savannah. Kwara State covers an area of 34,467.5 square kilometers and lies at latitude $8^{0} 30^{\prime} \mathrm{N}$ and longitude $5^{0} 00^{\prime} \mathrm{E}$. According to National Population Commission statistics of 2006 census, the State has a population of about 2,365,353 people and the main ethnic groups in the state are Yoruba, Hausa, Fulani and Nupe.

\section{Sampling Technique}

A three stage sampling technique was used for the study. The first stage involved a random selection of three Local Government Areas from the sixteen LGAs of the State. The second stage was a random selection of two villages from each of the three LGAs making a total of six villages. The final stage involved the selection of fifteen households from each of the six villages making a total of 90 households.

\section{Method of Data Collection}

The study made use of primary data. The primary data were obtained by means of a well structured questionnaire.

\section{Analytical Techniques}

Descriptive statistics such as frequency counts and percentages was used to describe the socioeconomic characteristics of the respondents. In analyzing the determinants of rural household income in the study area, multiple regression analysis was adopted. The regression model is specified as follows:

$$
\mathbf{Y}=\boldsymbol{\beta}_{0}+\boldsymbol{\beta}_{1} \mathbf{X}_{1}+\beta_{2} \mathbf{X}_{2}+\beta_{3} \mathbf{X}_{3}+\beta_{4} \mathbf{X}_{4}+\beta_{5} \mathbf{X}_{5}+\beta_{6} \mathbf{X}_{6}+\beta_{7} \mathbf{X}_{7}+e
$$

\section{Where,}

$Y=$ Total household income (Naira)

$\mathrm{X}_{1}=$ Age of the household head in years

$\mathrm{X}_{2}=$ Gender of the household head (Dummy

variable by Male $=1$, Female $=0$ )

$\mathrm{X}_{3}=$ Years of Education of the household head

$\mathrm{X}_{4}=$ Household size in number

$\mathrm{X}_{5}=$ Farm size in hectare

$\mathrm{X}_{6}=$ Access to electricity (Dummy variable by

Yes $=1, \mathrm{No}=0$ )

$\mathrm{X}_{7}=$ Access to credit (Dummy variable by

Yes $=1$, No $=0$ )

$\beta_{0}=$ the intercept

$\beta_{1} \ldots \beta_{7}=$ estimation parameters

$\mathrm{e}=$ the error term

\section{RESULTS AND DISCUSSION}

\section{Socio-economic Characteristics of the}

\section{Households}

The socioeconomic characteristics of the households are presented in Table 1. The result of the analysis showed that Male headed households $(91.1 \%)$ dominate in the study area. About $91 \%$ of the respondents were married with about $51 \%$ of the respondents having between 7 -
10 members per household. The average household size in the study area was 9. The relatively large household size can be linked to the practice of polygamy and the need for family labour in the area.

Age is an important socio-economic characteristic as strength for labour reduces with age. The modal age of the household heads in the study area is between $50-60$ years. The implication of this is that majority of the respondents in the study area are becoming old and less active which could affect their productivity and income level. Majority of the respondents $(54.4 \%)$ had only primary school education, while $16.7 \%$ had no formal education. The respondents who are predominantly farmers had a modal farm size 1.6-2.5 hectares and the average farm size was 1.89 hectares which indicates that most of the farmers own small area of land. $41 \%$ of the household heads belongs to a cooperative society. Farming is the primary occupation of majority of the household heads with about $98 \%$ of them having agriculture whis their major source of income. 
Table 1. Socio-economic characteristics of respondents $(n=90)$

Characteristics Frequency

Gender of the household head

Female

$\begin{array}{lr}8 & 8.9 \\ 82 & 91.1 \\ & \\ 82 & 91.1 \\ 8 & 8.9\end{array}$

Age of the household head

28-38

$39-49$

$50-60$

$61-71$

$>71$

Formal education of the household head

No formal education

$15 \quad 16.7$

Primary education

$49 \quad 54.4$

Secondary education

$22 \quad 24.4$

Tertiary education

$4 \quad 4.4$

\section{Household size}

3-6

7-10

11-14

$15-18$

\section{Farm size}

$0.5-1.5$

$1.6-2.5$

$2.6-3.5$

$>3.5$

\section{Primary Occupation}

Farming

Civil Service

\section{Cooperative membership}

Members

Non-members

Source: Field Survey Data, 2013

Households' Participation in different income sources
Table 2 gives a summary of share and participation of households in the different sources of the income.

Table 2. Participation in different income sources

\begin{tabular}{lcc}
\hline Income sources & $\begin{array}{c}\text { Share in total household } \\
\text { income }(\boldsymbol{\%})\end{array}$ & $\begin{array}{c}\text { Households participation rate } \\
(\boldsymbol{\%})\end{array}$ \\
\hline Total farm income & 57.9 & 97.8 \\
Crop income & 51.2 & 94.3 \\
Livestock income & 6.7 & 52.6 \\
Total off-farm income & 42.1 & 78.1 \\
Agric wage income & 5.7 & 20.1 \\
Non-agric wage income & 8.3 & 12.6 \\
Self-employed income & 24.7 & 42.5 \\
Remittance income & 3.4 & 2.9 \\
\hline
\end{tabular}

Source: Field Survey Data, 2013 
The result indicated that total farm income which is a combination of income from crop and livestock enterprises contributes $57.9 \%$ to total household income in the study area with $97.8 \%$ of the households participating in these activities. $78.1 \%$ of the sample households had access to the off-farm income which includes wage from agricultural labour services, wage from self-employment income and income from remittances. This shows that farm income remains the main source of income for the rural households. This result is in line with that of (10). Crop income which is the income derived from crop production such as planting of maize, cassava yam etc. accounted for about $51 \%$ of total farm income. About 53\% of the sample households participate in livestock farming, but income from this source is only $6.7 \%$ of total household income. This suggests that the livestock production activities for the rural households are mainly for consumption. Income from self employment which include activities such as hair dressing, tailoring, trading, shop- keeping and motor cycle transportation (Okada) account for $24.7 \%$ of total household income and $42.5 \%$ of the household heads participate in this activity.

Non-agricultural wage activities which include jobs in education, construction, manufacturing, health and other services contribute $8.3 \%$ to total household income and about $13 \%$ of the households participate. The smaller contribution of non-agricultural wage labour to total household income may be because of the low educational qualification of the rural farmers. About $20 \%$ of the sample households receive income from agricultural wage labour, which accounts for $5.7 \%$ of total household income. The least source of income is remittance which is the money received as gift and it accounts for only $3.4 \%$ of total household income, this shows that households in the study rarely depend on others to give them money.

Table 3. Multiple Regression Results

\begin{tabular}{|c|c|c|c|c|}
\hline Variables & Linear & Semi-log & Double-log & Exponential \\
\hline Constant & $\begin{array}{l}31249.1 \\
(2.016)\end{array}$ & $\begin{array}{l}-52821.9 \\
(0.746)\end{array}$ & $\begin{array}{l}4.498 \\
(12.966)\end{array}$ & $\begin{array}{l}10.780 \\
(26.124)\end{array}$ \\
\hline Age of the household head $\left(X_{1}\right)$ & $\begin{array}{l}-42393.3^{* *} \\
(-2.141)\end{array}$ & $\begin{array}{l}350791.6^{*} \\
(5.216)\end{array}$ & $\begin{array}{l}0.852 * \\
(7.360)\end{array}$ & $\begin{array}{l}-0.135 \\
(-0.080)\end{array}$ \\
\hline Gender of the household head $\left(\mathrm{X}_{2}\right)$ & $\begin{array}{l}2.295^{*} \\
(12.847)\end{array}$ & $\begin{array}{l}-5816.3 \\
(-0.428)\end{array}$ & $\begin{array}{l}-0.184 \\
(-0.787)\end{array}$ & $\begin{array}{l}-0.548 * * \\
(-2.225)\end{array}$ \\
\hline Years of education of the household head $\left(\mathrm{X}_{3}\right)$ & $\begin{array}{l}-5813.4 \\
(-0.953)\end{array}$ & $\begin{array}{l}-42953.4 \\
(-0.539)\end{array}$ & $\begin{array}{l}-0.0642 \\
(-0.421)\end{array}$ & $\begin{array}{l}0.326 * \\
(2.861)\end{array}$ \\
\hline Household size $\left(\mathrm{X}_{4}\right)$ & $\begin{array}{l}-3.687 \\
(-0.308)\end{array}$ & $\begin{array}{l}48822.6 \\
(0.303)\end{array}$ & $\begin{array}{l}-0.251 * * * \\
(-1.904)\end{array}$ & $\begin{array}{l}-0.0849 \\
(-1.212)\end{array}$ \\
\hline Farm size $\left(\mathrm{X}_{5}\right)$ & $\begin{array}{l}5727.7 * * \\
(2.178)\end{array}$ & $\begin{array}{l}243813.8 * * * \\
(1.941)\end{array}$ & $\begin{array}{l}0.316 \\
(1.162)\end{array}$ & $\begin{array}{l}0.109 * \\
(2.612)\end{array}$ \\
\hline Access to electricity $\left(\mathrm{X}_{6}\right)$ & $\begin{array}{l}85.266 \\
(0.075)\end{array}$ & $\begin{array}{l}26268.1 \\
(0.234)\end{array}$ & $\begin{array}{l}0.114 \\
(0.964)\end{array}$ & $\begin{array}{l}0.638 * * \\
(2.127)\end{array}$ \\
\hline Access to credit $\left(\mathrm{X}_{7}\right)$ & $\begin{array}{l}1163.8 \\
(1.215)\end{array}$ & $\begin{array}{l}-8867.7 \\
(-1.184)\end{array}$ & $\begin{array}{l}0.328 \\
(1.066)\end{array}$ & $\begin{array}{l}-0.122 \\
(-1.314)\end{array}$ \\
\hline $\begin{array}{l}\mathrm{R}^{2} \\
\text { F-value }\end{array}$ & $\begin{array}{l}0.362 \\
9.867\end{array}$ & $\begin{array}{l}0.286 \\
6.654\end{array}$ & $\begin{array}{l}0.335 \\
8.507\end{array}$ & $\begin{array}{l}0.395 \\
12.821\end{array}$ \\
\hline
\end{tabular}

Source: Data analysis, 2013; Figures in parenthesis are the t-ratios *, ** and $* * *$ are significant at $10 \%, 5 \%$ and $1 \%$ levels respectively.

\section{Factors influencing income distribution}

The factors influencing income distribution was examined. The regression is done for the linear, semi-log, double-log and exponential equation functional forms. The lead equation was found to be the exponential equation considering value of $\mathrm{R}^{2}, \mathrm{~F}$-value, the number of significant variables and the a priori expectations. From the lead 
equation, four of the explanatory variables; gender of the household head, years of the education of the household head, farm size and access to credit were the significant variables influencing household income in the study area.

The results showed that In regard to the gender of the household head, the variable's coefficient had a negative sign and was significant at the 5\% level, which indicates that total household income was higher for male-headed households than female-headed ones. Education of the household head was significant at $10 \%$ level and, its coefficient had a positive sign. This indicated that the higher the level of education of the household head, the higher the household total income. Household size was not significant and its coefficient had a negative sign. This may be due to the fact that most of the dependants were too young to contribute to the household's total income. Farm size had a positive impact on household income and was significant at $1 \%$ level. This indicates increased household farm size as a result of increased agricultural production. The result is similar to that obtained by (11) and (8). The variable for access to electricity had a positive sign and was significant at 5\% level. This showed that villages that were well supplied with electricity had higher total household incomes than those with electricity shortages.

\section{CONCLUSION}

The study assesses the determinants of income among rural households in Kwara State, Nigeria. Farm income is the most important source of income for rural households in the study area. The result of the multiple regression analysis with exponential functional form showed that level of education of the household head, farm size and access to electricity positively influenced total household income while gender of the household head negatively influenced total household income.

\section{Recommendations}

(i) Farm and non-farm economic activities should be promoted among rural households to accelerate income improvement.

(ii) Government should invest more in education and training in rural areas to equip young people with the knowledge and skill to secure good livelihoods and alleviate poverty.

(iii) Government should provide physical infrastructure such as adequate water and electricity supply because it would increase overall employment in the off-farm sector, and this could lead to income growth among poor households.

(iv) Farmers should be sensitized on the opportunities in off-farm economy.

(v) Women should be encouraged and empowered to participate more intensely in non-farm activities in order to reduce poverty and income inequality.

\section{REFERENCES}

1. World Bank. World development indicators 1999. Washington, D.C, 1999.

2. World Bank. World development report 2008: Agriculture for Development, Policy Washington, D.C. 2008.

3. Todaro, M.P. Economic Development, $7^{\text {th }}$ edition. Addison Wesley, p. 170., 2000

4. Chaudhry I. M., Malik S. and Ashraf M. Rural poverty in Pakistan: some related concepts, issues and empirical analysis Pakistan Economic and Social Review 44, (2): 259-276, 2006.

5. Adebayo, A.F., An evaluation of public policies for rural development in Nigeria, Geo Res.1: 65-73 1998.

6. Omotola, J.S. Combating Poverty for Sustainable Human Development in Nigeria: The Continuing Struggle. Journal of Poverty, 12(4), 496-517, 2008.

7. National Bureau of Statistics (NBS). Poverty Profile Report for Nigeria. Federal Government of Nigeria, Abuja 2010.

8. Adebayo, A.F. The Implications of Community Leadership for Rural

Development Planning in Nigeria. Community Development Journal, 20, 2431, 1985.

9. Olatona, M.O., (2007), Agricultural Production and Farmers Income in Afon District, Unpublished B.Sc. Project, Department of Geography, University of Ilorin.

10. Reardon, T., Stamouis, K., Balisacan, A., Cruz, M. E., Berdegue, J. and Banks, B. Rural non-farm income in developing countries. In: FAO (ed.). The State of Food and Agriculture 281-356. FAO, Rome: 1998.

11. Ibekwe, U.C. Determinants of income among farm households in Orlu Agricultural Zone of Imo State, Nigeria, Report and Opinion 2(8):32-35, 2010. 